PYTHAGORAS: Jurnal Pendidikan Matematika

Volume 10 - Nomor 2, Desember 2015, (155-167)

Available online at: http://journal.uny.ac.id/index.php/pythagoras

\title{
Pengembangan Perangkat Pembelajaran Materi Geometri Ruang SMP dengan Memanfaatkan Alat Peraga Manipulatif dan Lingkungan
}

\author{
Harna Yulistiyarini ${ }^{1)}$, Ali Mahmudi ${ }^{2)}$ \\ ${ }^{1}$ SMP Negeri 1 Dukuhseti Pati. Jalan Alasdowo Krajan, Dukuhseti, Pati, Jawa Tengah, Indonesia. \\ Email: harnayulistiyarini@gmail.com \\ ${ }^{2}$ Pendidikan Matematika, Universitas Negeri Yogyakarta, Jalan Colombo No. 1, Karangmalang, \\ Yogyakarta 55281, Indonesia. Email: ali_uny73@gmail.com
}

\begin{abstract}
Abstrak
Penelitian ini bertujuan menghasilkan perangkat pembelajaran materi geometri ruang SMP dengan memanfaatkan alat peraga manipulatif dan lingkungan yang valid, praktis, dan efektif. Penelitian pengembangan ini menggunakan model pengembangan Four-D yang dimodifikasi menjadi tiga tahap: pendefinisian, perancangan, dan pengembangan. Uji pengembangan dilakukan di SMP N 1 Dukuhseti, Pati, Jawa Tengah. Instrumen pengumpulan data meliputi lembar validasi perangkat, lembar observasi keterlaksanaan pembelajaran, lembar penilaian kepraktisan perangkat, dan instrumen penilaian hasil belajar. Analisis data dilakukan secara deskriptif kuantitatif. Hasil penelitian ini berupa perangkat pembelajaran yaitu: RPP, LKS, Lembar Observasi Sikap (LOS) dan Tes Hasil Belajar (THB) dengan tingkat kevalidan 100\%. Tingkat kepraktisan LKS, RPP, dan LOS 100\% sedangkan tingkat kepraktisan THB 84,36\%. Tingkat keterlaksanaan pembelajaran 97\%. Tingkat keefektifan RPP dan LKS $81 \%$. Dapat disimpulkan bahwa produk hasil pengembangan yang berupa RPP dan LKS memenuhi kriteria valid, praktis, dan efektif, sedangkan instrumen penilaian yang berupa LOS dan THB memenuhi kriteria valid dan praktis.
\end{abstract}

Kata Kunci: alat peraga manipulatif, geometri ruang, lingkungan, pengembangan perangkat.

\section{Developing Instructional Materials in Space Geometry for Junior High School Using Manipulative Visual Aids and Environment}

\begin{abstract}
The aims of this research was to result instructional materials in space geometry for junior high school using manipulative visual aids and environment that valid, practical, and effective. This development research using the Four-D development model with modification in three steps: define, design, and develop. The development testing was carried out in SMP N 1 Dukuhseti, Pati, Central Java. The research instruments were a validation sheet, teaching implementation observation sheet, practicality assessment sheet, and competency assessment instrument. The data analysis was conducted quantitative descriptively. This research produced instructional materials including lesson plans, student's worksheets, observation sheet of attitude, and assessment instrument with the level of validity of the product reached $100 \%$. The degree of practicality lesson plans, worksheets, and observation sheet of attitude were 100\%, while the rate of assessment instrument of learning achievement practicality was $84.36 \%$. The level of learning was $97 \%$. The degree of effectiveness of the lesson plans and worksheets products reached $81 \%$. Therefore, it can be concluded that the instructional materials in the form of lesson plans and worksheets were valid, practical, and effective, while the form of assessment instruments observation sheet of attitude, and assessment instrument of learning achievement were valid and practical.
\end{abstract}

Keywords: manipulative visual aid, space geometry, environment, instructional development.

How to Cite Item: Yulistiyarini, H., \& Mahmudi, A. (2015). Pengembangan perangkat pembelajaran materi geometri ruang SMP dengan memanfaatkan alat peraga manipulatif dan lingkungan. PYTHAGORAS: Jurnal Pendidikan Matematika, 10(2), 155-167. Retrieved fromhttp://journal.uny.ac.id/index.php/pythagoras/article/view/9145 


\section{Pythagoras, 10 (2), Desember 2015 - 156}

Harna Yulistiyarini, Ali Mahmudi

\section{PENDAHULUAN}

Salah satu materi pada mata pelajaran matematika SMP adalah geometri ruang. Pentingnya materi geometri bagi siswa SMP dikemukakan oleh Goos, Stillman, \& Vale (2007, pp. 200-201) yang menyatakan bahwa ada banyak hubungan antara geometri dengan konsep matematika lainnya. Geometri juga menyediakan konteks penting untuk mengembangkan bernalar dan berpikir di semua bidang matematika. Kennedy, Tipps, \& Johnson, (2008, p.432) juga menyebutkan bahwa geometri ruang merupakan materi matematika yang penting untuk dipelajari karena berkaitan dengan kehidupan sehari-hari seperti desain bangunan dan busana, seni budaya, animasi, pengepakan, dan sebagainya.

Materi geometri ruang menjadi materi pokok yang diajarkan kepada siswa SMP dan diujikan dalam Ujian Nasional (UN) di Indonesia. Permendikbud Nomor 58 Tahun 2014 tentang Kurikulum 2013 SMP/MTs menyebutkan Kompetensi Dasar (KD) SMP kelas VIII materi geometri ruang yaitu KD 3.9 menentukan luas permukaan dan volume kubus, balok, prisma, dan limas; serta KD 3.11 menaksir dan menghitung luas permukaan dan volume geometri ruang yang tidak beraturan dengan menerapkan geometri dasarnya. Materi geometri ruang kelas IX meliputi KD 3.7 menentukan luas selimut dan volume tabung, kerucut, dan bola; serta KD 3.8 menaksir dan menghitung luas permukaan geometri ruang yang tidak beraturan dengan menerapkan kombinasi geometri dasarnya.

Meskipun penting, hasil belajar matematika siswa pada materi geometri ruang SMP masih rendah. Data Balitbang Kemdikbud selama tujuh tahun terakhir tentang daya serap UN SMP menunjukkan bahwa secara nasional kemampuan geometri ruang belum pernah mencapai angka ketuntasan 70\%. Dari data Balitbang, daya serap materi geometri ruang pada UN tahun 2008 mencapai 55\%, tahun 2009 mencapai $67 \%$, tahun 2010 mencapai 68\%, tahun 2011 mencapai 67\%, tahun 2012 mencapai $66 \%$, tahun 2013 mencapai $46 \%$, dan pada tahun 2014 mencapai 61\%. Hal ini perlu mendapatkan perhatian yang serius, supaya pada tahun pelajaran mendatang, daya serap siswa pada materi ini dapat meningkat.

Belum tercapainya hasil belajar yang diharapkan tersebut diduga karena kurangnya perencanaan pembelajaran termasuk pemilihan media atau sumber belajar. Media atau sumber belajar yang dipilih dan disiapkan dengan cermat dapat mendukung pencapaian tujuan pembelajaran yang diharapkan. Sumber belajar yang tepat akan memotivasi siswa dengan cara menarik perhatian pada materi pembelajaran, melibatkan siswa, menjelaskan dan menggambarkan materi dan keterampilan-keterampilan kinerja, membantu pembentukan sikap dan pengembangan rasa menghargai (apresiasi), serta memberi kesempatan untuk menganalisis sendiri kinerja individual (Trianto, 2009, p.185).

Menurut AECT (Januszewski \& Molenda, 2008, pp. 216-238), ada dua jenis sumber belajar yaitu sumber belajar yang sengaja dibuat (resources by design) dan sumber belajar yang dapat langsung digunakan (resources by utilization). Sumber belajar yang sengaja dibuat misalnya peralatan, teknologi, dan material atau bahan yang didesain untuk membantu siswa. Sumber belajar yang dapat langsung digunakan misalnya benda atau peristiwa sehari-hari yang digunakan sesuai tujuan pembelajaran. Majid (2013, pp.170-171) menyatakan bahwa sumber belajar adalah tempat atau lingkungan sekitar, benda dan orang yang mengandung informasi dan dapat digunakan sebagai wahana bagi peserta didik untuk melakukan proses belajar. Dari pengertian tersebut, segala sesuatu yang dapat digunakan untuk belajar merupakan sumber belajar. Pemanfaatan sumber belajar yang tepat akan mendukung suksesnya pembelajaran. Pada penelitian ini sumber belajar yang digunakan berupa alat peraga manipulatif (APM) dan lingkungan.

Menurut Kelly (2006, p.184) alat peraga manipulatif adalah objek yang dapat dipegang, alat, atau model yang digunakan untuk menunjukkan pemahaman lebih dalam, khususnya pada topik-topik matematika. Moyer (Drews \& Hansen, 2007, p.21) menyatakan bahwa "specific mathematical apparatus, or manipulatives are objects designed to represent explicitely and concretely mathematical ideas that are abstract". Posamentier, Smith, \& Stepelman (2010, p.6) menyatakan bahwa "hands-on material or manipulatives are tangible objects that students can explore, arrange, move around, group, sort, and use to measure as they model mathematical concepts and problems". Smaldino, Lowther, \& Russel (2008, p.216) menyatakan bahwa "manipulatives are objects that can be viewed and handle in learning setting". Dari berbagai pendapat tersebut, dapat disimpulkan bahwa APM atau alat peraga 


\section{Pythagoras, 10 (2), Desember 2015 - 157}

Harna Yulistiyarini, Ali Mahmudi

manipulatif adalah benda nyata yang didesain untuk menyajikan konsep matematika secara konkret sehingga dapat digunakan siswa atau guru untuk mencapai tujuan pembelajaran. APM digunakan melalui peragaan dengan dilihat, dipegang, diotak-atik, dan sebagainya sehingga memberikan pengalaman belajar kepada siswa.

Ada beberapa alasan mengapa APM digunakan dalam pembelajaran matematika. Burns (2007, pp.33-35) menyatakan bahwa penggunaan APM akan membantu siswa memahami ide abstrak matematika, membuktikan ide matematika, menyelesaikan masalah matematika, dan membuat pembelajaran matematika lebih menarik, menantang serta memotivasi siswa untuk belajar secara aktif. Frei (2008, p.101) menyatakan bahwa siswa lebih memahami konsep matematika ketika diberi kesempatan untuk melakukan pengalaman nyata menggunakan APM sehingga siswa bersikap lebih positif terhadap matematika. Cope (2015, p.16) menunjukkan bahwa manipulatif berpotensi untuk membantu mengkonkretkan ide abstrak, menyediakan model tiga dimensi, sebagai alat pemecahan masalah, membuat pembelajaran matematika menjadi lebih menarik dan menyenangkan, dan membangun kepercayaan siswa.

Mink (2010, p.71) memaparkan bahwa "the value of the manipulatives is not in the cost, but in its use. Matching the manipulatives to mathematical concept is the most important step that any teacher during lesson preparation". Kamina \& Iyer (2009: 1) menambahkan "one of the most important uses of manipulatives in a classroom is to aid a learner to make connection from tangible concrete object to its abstraction". Arsyad (2011, p.75) mengungkapkan bahwa dalam memilih media pembelajaran kriteria yang harus diperhatikan adalah kesesuaian dengan tujuan pembelajaran dan ketepatan dalam mendukung pembelajaran yang sifatnya fakta, konsep, prinsip, atau generalisasi. Jadi, hal terpenting yang harus diperhatikan dalam memilih jenis APM yang akan digunakan adalah kesesuaian APM dengan tujuan pembelajaran dan konsep matematika yang diajarkan.

Selain APM, untuk menyukseskan tujuan Kurikulum 2013 perlu didayagunakan lingkungan sebagai sumber belajar secara optimal (Mulyasa, 2014, p.106). Jadi, lingkungan dapat dikatakan sebagai salah satu sumber belajar. Hamalik (2005, p.194-196) memaparkan tentang pandangan para ahli masa lampau seperti Rosseau, Ligthart, dan Decroly bahwa lingkungan menjadi dasar pengajaran yang penting.
Lingkungan adalah sesuatu yang ada di alam sekitar yang memiliki makna dan pengaruh tertentu terhadap individu. Lingkungan sebagai dasar pengajaran adalah faktor kondisional yang mempengaruhi tingkah laku individu dan merupakan faktor belajar.

Penggunaan lingkungan sebagai sumber belajar matematika diungkapkan Brunner (Adams \& Hamm, 1994, p.190) bahwa "a learning environment in the mathematics classroom encourages exploration, presents mathematical ideas in concrete manner and does not equate failure with punishment". Menurut Adams \& Hamm "in this learning environment, students are encouraged to explore with manipulatives to find mathematical solutions". Jadi, lingkungan belajar diharapkan dapat memfasilitasi siswa untuk bereksplorasi dalam menyelesaikan permasalahan matematika.

Pemanfaatan lingkungan dalam pembelajaran telah direkomendasikan Permendikbud Nomor 58 Tahun 2014 tentang Kurikulum 2013 SMP/MTs terutama pada model pembelajaran kontekstual. Pembelajaran kontekstual mengasumsikan bahwa secara natural pikiran mencari makna konteks sesuai dengan situasi nyata lingkungan seseorang melalui pencarian hubungan logis dan bermanfaat. Perpaduan materi yang dipelajari dengan pengalaman keseharian siswa menghasilkan pengetahuan yang mendalam. Siswa akan mampu menggunakan pengetahuannya untuk menyelesaikan masalahmasalah baru yang belum pernah dihadapinya dengan peningkatan pengalaman dan pengetahuannya. Siswa diharapkan dapat membangun pengetahuannya yang akan diterapkan dalam kehidupan sehari-hari berdasarkan materi pelajaran yang telah diterimanya di sekolah. Berdasarkan pada pemikiran tersebut, maka pembelajaran matematika perlu diawali dengan mengangkat permasalahan di lingkungan siswa yang sesuai dengan materi pembelajaran.

Guru perlu menentukan lingkungan sebagai sumber belajar yang sesuai dengan materi yang akan dipelajari siswa dan mengaitkan materi dengan kehidupan sehari-hari siswa sehingga pembelajaran lebih bermakna. Hal ini sesuai dengan Muijs \& Reynold (2008, p. 341) tentang penggunaan konteks-konteks riil pada pembelajaran matematika untuk mengatasi kesulitan siswa dalam mengaitkan matematika dengan berbagai situasi riil. Selain itu, menurut Muijs \& Reynold, materi-materi yang dibawa ke kelas akan meningkatkan keterlibatan siswa dalam pembelajaran. Sadiman, Rahardjo, 


\section{Pythagoras, 10 (2), Desember 2015 - 158}

Harna Yulistiyarini, Ali Mahmudi

Haryono, et al (2011, pp.5-6) menyatakan lingkungan atau setting yang memungkinkan siswa untuk belajar dapat digunakan sebagai sumber belajar. Gedung sekolah, perpustakaan, laboratorium, pabrik, dan tempat lain baik yang sengaja dirancang untuk tempat belajar siswa atau dirancang untuk tujuan lain dapat dimanfaatkan sebagai sumber belajar.

Lingkungan sebagai sumber belajar matematika pada penelitian ini adalah benda dan masalah nyata di sekitar siswa yang dapat digunakan untuk mencapai tujuan pembelajaran matematika. Pemanfaatan benda dan masalah nyata di sekitar siswa memungkinkan ide-ide matematika yang abstrak dapat lebih dipahami oleh siswa.

Pemanfaatan APM dan lingkungan secara optimal diduga dapat meningkatkan hasil belajar, minat, dan aktivitas siswa. Hal ini didasarkan pada berbagai penelitian sebelumnya diantaranya Goracke (2009), Ojose \& Sexton (2009), Al-Absi \& Noval (2010), Kosko \& Wilkins (2010), serta Boggan, Harper, \& Whitmire (2010). Hasil penelitian tersebut diperkuat oleh Groth (2013, p.61-62) bahwa untuk memahami beberapa ide matematika yang abstrak siswa SMP masih memerlukan APM. Sementara itu, mengenai pentingnya lingkungan, Baur \& Pigford (1984, p.15) mengemukakan "...each of our students is a reflection of his or her environment". Hal ini memberikan indikasi bahwa lingkungan sangat mempengaruhi pencapaian hasil belajar siswa.

Dari survei pendahuluan juga didapatkan informasi bahwa pada tahun 2010, SMP-SMP di Kabupaten Pati telah mendapatkan bantuan Alat Peraga Manipulatif (APM) dari Dinas Pendidikan berupa model bangun ruang balok, kubus, prisma segitiga, dan limas segiempat. APM tersebut bisa digunakan untuk mengenalkan jenis dan unsur-unsur bangun ruang, namun belum dapat dimanipulasikan untuk materi jaring-jaring, luas, dan volume bangun ruang. Selain itu, keterbatasan jumlah alat peraga menjadikan tidak semua siswa memiliki kesempatan untuk menggunakannya. Oleh karena itu, diperlukan penggunaan benda di lingkungan sekitar serta pengembangan APM untuk mengatasi masalah tersebut.

Pemanfaatan APM dan lingkungan sebagai sumber belajar dapat bersifat saling melengkapi sehingga dapat tercapai tujuan pembelajaran. APM geometri ruang yang sudah ada di sekolah bisa digunakan untuk pembelajaran di kelas. Jika belum ada APM tersebut, guru dapat menggunakan benda di lingkungan sekitar yang dapat digunakan sebagai alat peraga. Selain itu, guru dapat membuat APM yang diperlukan tetapi belum tersedia di lingkungan sekitar.

Permasalahan di lingkungan sekitar dapat digunakan untuk meningkatkan kemampuan siswa dalam menyelesaikan masalah maupun mendorong siswa melakukan penyelidikan terkait materi geometri ruang. Penggunaan konteks dari lingkungan sekitar terkait bangun geometri ruang tertentu dapat divisualisasikan dengan membawa benda berbentuk bangun geometri ruang tertentu ke kelas maupun melalui gambar maupun disajikan di Lembar Kegiatan Siswa (LKS). Secara umum APM dan lingkungan dapat digunakan saat kegiatan pendahuluan maupun kegiatan inti pembelajaran.

Berdasarkan penjelasan tersebut, maka perlu dilakukan perencanaan yang matang agar pemanfaatan APM dan lingkungan dapat sesuai dengan tujuan pembelajaran. Perencanaan tersebut berupa mempersiapkan perangkat pembelajaran yang memuat penggunaan APM dan lingkungan sesuai dengan kurikulum yang berlaku (Kurikulum 2013). Oleh karena itu, tujuan penelitian ini adalah menghasilkan perangkat pembelajaran materi geometri ruang SMP berbasis Kurikulum 2013 yang memanfaatkan APM dan lingkungan serta mendeskripsikan kualitas perangkat yang dihasilkan ditinjau dari kevalidan, kepraktisan, dan keefektifan.

\section{METODE}

\section{Prosedur Penelitian}

Penelitian ini menggunakan model pengembangan Four-D yang dikembangkan oleh Thiagarajan, Semmel, \& Semmel (1974, pp.5-9) dengan modifikasi meliputi tahap pendefinisian (define), perancangan (design), dan pengembangan (develop). Tahap keempat yaitu penyebaran (disseminate) tidak dilakukan karena keterbatasan waktu dan sumber daya. 


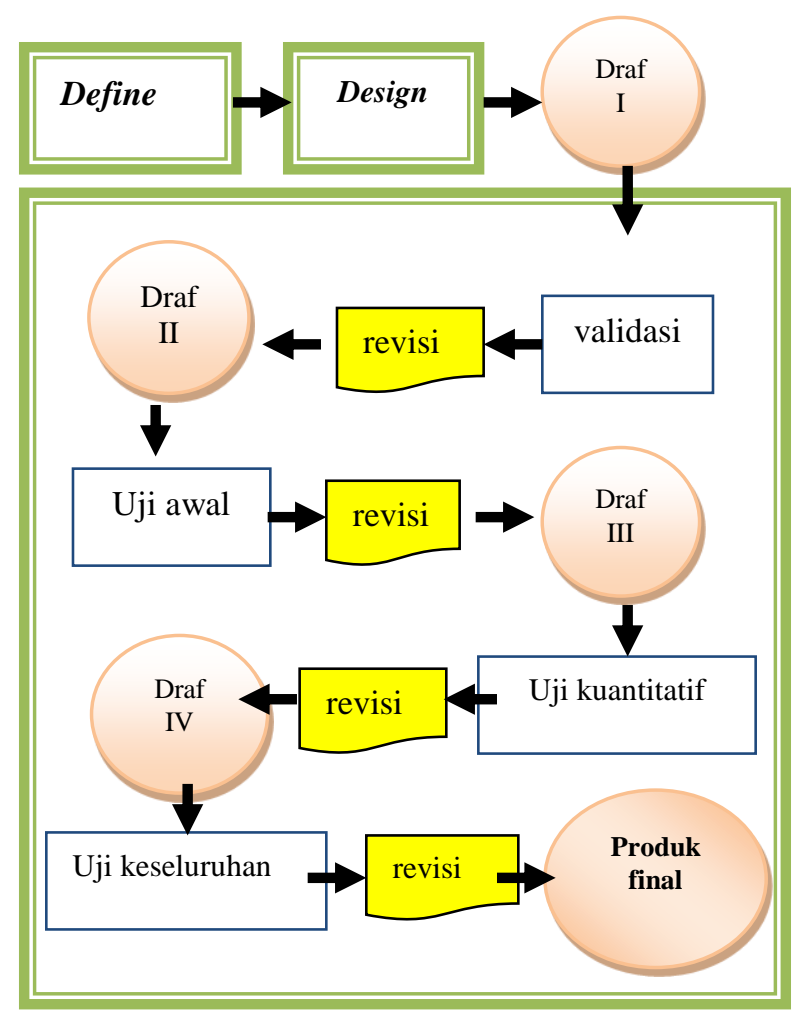

Gambar 1. Alur Penelitian

Tahap Define meliputi analisis awal akhir, analisis siswa, analisis tugas, analisis konsep, penyusunan tujuan pembelajaran khusus. Analisis awal akhir dilakukan dengan observasi, kajian tentang Kurikulum 2013, kajian literatur dan penelitian sebelumnya, serta kajian terhadap perangkat pembelajaran yang telah ada untuk menetapkan masalah mendasar yang akan diteliti serta alternatif penyelesaian masalah yang akan digunakan. Analisis siswa dilakukan dengan wawancara dan observasi, serta analisis nilai sikap, pengetahuan, dan keterampilan siswa pada materi sebelumnya sehingga dihasilkan rekapitulasi karakteristik siswa, berupa kompetensi yang telah dimiliki siswa, latar belakang pengalaman siswa, sikap terhadap materi pembelajaran yang diteliti, dan kecenderungan media, format serta bahasa yang dipilih. Analisis tugas dilakukan dengan mengkaji Kompetensi Dasar (KD) yang harus dicapai sehingga menghasilkan indikator ketercapaian kompetensi sikap, pengetahuan, dan keterampilan yang dikembangkan selama proses pembelajaran geometri ruang SMP. Analisis konsep dilakukan dengan mengidentifikasi konsep-konsep materi geometri ruang dan menyusunnya secara berurutan sesuai dengan kompetensi dasar. Setelah dilakukan analisis konsep dan tugas, maka dibuat tujuan pembelajaran dengan menggunakan kata kerja operasional.
Tahap Design meliputi penyusunan tes beracuan kriteria, pemilihan media, pemilihan format, perancangan awal Draf I Perangkat. Penyusunan tes beracuan pada kriteria kompetensi yang harus dicapai siswa dengan berdasarkan tujuan pembelajaran khusus. Pemilihan media dilakukan berdasarkan hasil identifikasi tentang media yang tepat untuk pembelajaran geometri ruang SMP. Pemilihan format dilakukan dengan mengkombinasikan media yang dipilih, strategi, dan teknik pengajaran. Setelah dipilih format dan media yang digunakan, maka dibuat rancangan awal perangkat pembelajaran yang dikembangkan. Hasil dari perancangan awal ini disebut Draf I Perangkat yang berupa Rencana Pelaksanaan Pembelajaran (RPP), Lembar Kegiatan Siswa (LKS), Lembar Observasi Sikap (LOS), dan Tes Hasil Belajar (THB).

Tahap Develop meliputi penilaian ahli dan uji pengembangan (uji coba lapangan). Penilaian ahli terhadap Draf I Perangkat dilakukan oleh ahli bidang pendidikan matematika dan ahli materi (Drs. Sugiyono, M.Pd) dan ahli asessmen (Dr. Heri Retnawati). Hasil validasi Draf I Perangkat kemudian dianalisis. Jika hasil analisis valid, maka Draf I Perangkat menjadi Draf II Perangkat yang siap digunakan untuk uji pengembangan. Jika hasil analisis tidak valid, maka dilakukan revisi dan diajukan kepada dosen ahli untuk dilakukan validasi, sampai diperoleh perangkat yang valid. Setelah diperoleh perangkat yang valid (Draf II Perangkat), tahapan selanjutnya adalah uji pengembangan. Uji pengembangan dilaksanakan di SMP N 1 Dukuhseti Kabupaten Pati Provinsi Jawa Tengah pada bulan April - Juni 2015 (semester genap)

Uji pengembangan meliputi uji awal (initial testing), uji kuantitatif (quantitative testing), dan uji keseluruhan (total packagetesting). Dari setiap tahap dilakukan revisi perangkat berdasarkan respon siswa, serta komentar dan saran dari guru saat menggunakan perangkat. Selain itu, dilakukan penilaian kepraktisan dan keefektifan perangkat. Jika hasil revisi ini telah praktis dan efektif, menjadi produk final yang siap didesiminasikan.

Kegiatan pada uji awal (initial testing) adalah pembelajaran yang dilakukan secara individual dan kelompok kecil secara langsung oleh peneliti. Sebanyak sembilan siswa kelas IX-A yang komunikatif ditunjuk untuk mewakili siswa kemampuan atas, sedang, dan bawah selama tiga pertemuan. Pertemuan pertama, siswa secara berkelompok melakukan penyelidikan menggunakan alat peraga sesuai petunjuk LKS 


\section{Pythagoras, 10 (2), Desember 2015 - 160}

Harna Yulistiyarini, Ali Mahmudi

di hadapan peneliti. Pertemuan ke-2, siswa membaca dan mengerjakan soal-soal latihan di LKS. Pertemuan ke-3 siswa membaca dan mengerjakan soal-soal THB. Jika ada bagian di LKS dan soal THB yang belum jelas, siswa bertanya langsung kepada peneliti atau memberi tanda pada bagian LKS dan soal THB yang perlu direvisi. Pada tahap ini peneliti melakukan observasi tentang respon, komentar, dan reaksi dari siswa.

Kegiatan pada uji kuantitatif (quantitative testing) yaitu guru melaksanakan pembelajaran sebenarnya di kelas VIII-A (22 siswa) dengan arahan peneliti. Kemudian observer mengamati keterlaksanaan proses pembelajaran. Tahap ini dilaksanakan selama sembilan pertemuan. Setiap selesai pembelajaran guru memberikan masukan dan saran tentang bagian yang harus direvisi. Pada pertemuan terakhir, guru dan 22 siswa kelas VIII-A melakukan penilaian kepraktisan perangkat. Guru dan siswa menuliskan kesan dan komentar terhadap perangkat yang dikembangkan. Selain itu, pada setiap pertemuan guru menilai sikap siswa menggunakan lembar observasi sikap. Setelah selesai pembelajaran selama sembilan pertemuan, siswa menyelesaikan tes hasil belajar (THB). Hasil dari THB siswa digunakan untuk menilai ketercapaian kompetensi pengetahuan dan keterampilan siswa.

Kegiatan pada tahap uji keseluruhan yaitu guru melaksanakan pembelajaran sebenarnya di kelas VIII-E tanpa arahan peneliti. Observer melakukan penilaian keterlaksanaan pembelajaran. Pada pertemuan terakhir, guru dan 21 siswa kelas VIII-E melakukan penilaian kepraktisan perangkat. Selain itu, siswa mengerjakan Tes Hasil Belajar. Hasil tes siswa ini digunakan sebagai evaluasi ketercapaian tujuan pembelajaran.

\section{Instrumen Penelitian}

Instrumen penelitian yang digunakan dalam penelitian ini diklasifikasikan menjadi tiga macam yaitu instrumen untuk mengukur kevalidan, kepraktisan, dan keefektifan perangkat.

Instrumen untuk mengukur kevalidan perangkat yang dikembangkan meliputi Lembar Validasi RPP, Lembar Validasi LKS, Lembar Validasi LOS, dan Lembar Validasi THB. Lembar validasi tersebut berupa checklist. Cara menggunakannya adalah dengan memberikan tanda centang pada pilihan kriteria valid dan tidak valid. Lembar validasi ini digunakan oleh ahli pendidikan matematika pada saat penilaian ahli pada tahap develop yaitu sebelum digunakan untuk uji pengembangan.

Tabel 1 Instrumen Kevalidan Perangkat

\begin{tabular}{|c|c|}
\hline Instrumen & Aspek Penilaian \\
\hline $\begin{array}{c}\text { Lembar Validasi } \\
\text { RPP }\end{array}$ & $\begin{array}{l}\text { KI, KD, indikator, Deskripsi } \\
\text { materi, Kegiatan pembelajaran, } \\
\text { Penilaian dan tindak lanjut, } \\
\text { Penggunaan APM dan } \\
\text { lingkungan, Bahasa }\end{array}$ \\
\hline $\begin{array}{l}\text { Lembar Validasi } \\
\text { LKS }\end{array}$ & $\begin{array}{l}\text { Kegiatan saintifik ( } 5 \mathrm{M}) \text {, Latihan } \\
\text { soal, Desain LKS, Bahasa }\end{array}$ \\
\hline $\begin{array}{l}\text { Lembar Validasi } \\
\text { Lembar Observasi } \\
\text { Sikap (LOS) }\end{array}$ & Substansi, Kontruksi, Bahasa \\
\hline $\begin{array}{c}\text { Lembar Validasi } \\
\text { Tes Hasil Belajar } \\
\text { (THB) }\end{array}$ & Substansi, Kontruksi, Bahasa \\
\hline
\end{tabular}

Instrumen untuk mengukur kepraktisan perangkat yang dikembangkan berupa Lembar Penilaian Kepraktisan oleh Guru, Lembar Penilaian Kepraktisan oleh Siswa, dan Lembar Keterlaksanaan Pembelajaran. Cara memberikan penilaian kepraktisan yaitu dengan memberikan tanda centang pada kolom ya atau tidak. Lembar penilaian ini digunakan oleh guru dan siswa setelah pembelajaran uji pengembangan tahap uji kuantitatif dan tahap uji keseluruhan.

Tabel 2 Instrumen Kepraktisan Perangkat

\begin{tabular}{ll}
\hline \multicolumn{1}{c}{ Instrumen } & \multicolumn{1}{c}{ Aspek Penilaian } \\
\hline Lembar Penilaian & Keterbacaan dan kemudahan \\
Kepraktisan oleh & $\begin{array}{l}\text { penggunaan RPP, LKS, LOS, } \\
\text { THB }\end{array}$ \\
$\begin{array}{l}\text { Lembar Penilaian } \\
\text { Kepraktisan oleh }\end{array}$ & $\begin{array}{l}\text { Keterbacaan dan kemudahan } \\
\text { penggunaan LKS dan THB } \\
\text { Siswa }\end{array}$ \\
Lembar Observasi & $\begin{array}{l}\text { Keterlaksanaan kegiatan } \\
\text { Keterlaksanaan }\end{array}$ \\
pendahuluan, inti, dan penutup \\
Pembelajaran & (guru dan siswa) \\
\hline
\end{tabular}

Lembar Observasi Keterlaksanaan Pembelajaran digunakan oleh observer untuk menilai keterlaksanaan pembelajaran. Observasi ini dilakukan pada saat proses pembelajaran pada uji pengembangan tahap uji kuantitatif dan tahap uji keseluruhan. Cara menilai adalah dengan memberi tanda centang pada pilihan kriteria terlaksana dan tidak terlaksana untuk setiap item langkah pembelajaran serta memberi catatan pada keterangan tentang hal-hal yang perlu menjadi perhatian peneliti.

Instrumen untuk mengukur keefektifan perangkat yang dikembangkan berupa Lembar Observasi Sikap (LOS) dan Tes Hasil Belajar (THB). LOS digunakan guru untuk menilai sikap spiritual dan sosial siswa saat proses 


\section{Pythagoras, 10 (2), Desember 2015 - 161}

Harna Yulistiyarini, Ali Mahmudi

pembelajaran pada tahap uji kuantitatif dan uji keseluruhan. THB digunakan guru untuk menilai pengetahuan dan keterampilan siswa. THB digunakan setelah akhir pembelajaran uji kuantitatif dan uji keseluruhan. THB merupakan soal tertulis berbentuk pilihan ganda untuk menilai ketercapaian kompetensi pengetahuan siswa dan soal uraian untuk menilai ketercapaian kompetensi keterampilan siswa.

\section{Analisis Data}

Analisis kevalidan perangkat pembelajaran (RPP, LKS, LOS, dan THB) dilakukan secara secara deskriptif. Hasil validasi ahli berupa penilaian umum yaitu valid dan tidak valid. Apabila ada indikator yang belum valid maka dilakukan revisi dan konsultasi dengan ahli. Proses revisi terus dilakukan sampai dihasilkan perangkat yang valid dan siap untuk digunakan uji coba.

Analisis kepraktisan perangkat pembelajaran dilakukan dengan menghitung persentase keterlaksanaan pembelajaran, serta hasil penilaian kepraktisan perangkat oleh guru dan siswa. Pada penelitian ini, perangkat dikatakan praktis jika lebih dari $75 \%$ kegiatan terlaksana dan persentase rata-rata hasil penilaian kepraktisan perangkat oleh siswa dan guru mencapai lebih dari $75 \%$.

Analisis keefektifan perangkat pembelajaran diukur dari ketercapaian tujuan pembelajaran. Tingkat ketercapaian tujuan pembelajaran dalam penelitian ini ditentukan berdasarkan hasil belajar siswa pada aspek sikap, pengetahuan, dan keterampilan. Pada penelitian ini, perangkat dikatakan efektif jika lebih dari $75 \%$ siswa mencapai nilai ketuntasan yang telah ditentukan. Ketuntasan setiap siswa ditentukan dengan mengacu Permendikbud Nomor 104 Tahun 2014 tentang Penilaian Hasil Belajar oleh Pendidik pada Pendidikan Dasar dan Pendidikan Menengah. Ketuntasan kompetensi siswa ditentukan dari modus sikap ditetapkan dengan predikat baik (B); skor rerata untuk ketuntasan kompetensi pengetahuan minimal 2,67; dan capaian optimum untuk ketuntasan kompetensi keterampilan minimal 2,67.

\section{HASIL DAN PEMBAHASAN}

Produk yang dihasilkan meliputi RPP, LKS, dan instrumen penilaian hasil belajar yaitu LOS dan THB. Implementasi APM dan lingkungan pada kegiatan pembelajaran tertuang di RPP dan LKS. Pemanfaatan APM dan lingkungan sebagai sumber belajar bersifat saling melengkapi sehingga dapat tercapai tujuan pembelajaran. Oleh karena itu, perlu identifikasi pada saat perencanaan pembelajaran tentang ketersediaan APM dan lingkungan yang dibutuhkan. APM geometri ruang yang sudah ada di sekolah bisa digunakan untuk pembelajaran di kelas. Jika belum ada APM tersebut, guru dapat menggunakan benda di lingkungan sekitar yang dapat digunakan sebagai alat peraga. Selain itu, guru dapat membuat APM yang diperlukan tetapi belum tersedia di lingkungan sekitar.

Permasalahan di lingkungan sekitar dapat digunakan untuk meningkatkan kemampuan siswa dalam menyelesaikan masalah maupun mendorong siswa melakukan penyelidikan terkait materi geometri ruang. Penggunaan konteks dari lingkungan sekitar terkait bangun geometri ruang tertentu dapat divisualisasikan dengan membawa benda berbentuk bangun geometri ruang tertentu ke kelas maupun melalui gambar maupun disajikan di Lembar Kegiatan Siswa (LKS). Secara umum APM dan lingkungan dapat digunakan saat kegiatan pendahuluan maupun kegiatan inti pembelajaran.

Pada saat kegiatan pendahuluan, guru dapat memutar video atau menunjukkan benda atau gambar berbentuk bangun ruang yang sedang dipelajari. Hal ini akan menarik siswa untuk mempelajari materi karena siswa merasa materi tersebut bermanfaat bagi kehidupan sehari-hari.

Implementasi APM dan lingkungan dalam kegiatan inti pembelajaran dapat diwujudkan dengan langkah-langkah meliputi mengamati masalah sehari-hari di lingkungan sekitar siswa, menanya proses penyelesaian masalah, membaca beberapa informasi terkait materi, melakukan penyelidikan dengan menggunakan APM untuk menentukan rumus luas dan volume bangun ruang, mempresentasikan hasil penyelidikan, dan menyelesaikan permasalahan, mengerjakan latihan, dan membahasnya.

Kegiatan mengamati berbagai permasalahan sehari-hari di lingkungan sekitar siswa dapat disajikan di LKS. Siswa mengamati dengan membaca permasalahan tersebut dan menuliskan hasil pengamatannya di LKS. Setelah siswa mengamati masalah, siswa didorong untuk bertanya tentang hal-hal yang ingin diketahui atau diselidiki. Guru mengarahkan agar pertanyaan siswa sesuai dengan tujuan pembelajaran atau terkait dengan proses penyelesaian masalah.Setelah guru menetapkan tentang pertanyaan siswa yang akan digunakan untuk dasar penyelidikan, siswa diminta 


\section{Pythagoras, 10 (2), Desember 2015 - 162}

Harna Yulistiyarini, Ali Mahmudi

membaca berbagai informasi terkait materi. Contoh, pada materi volume balok, siswa mengumpulkan informasi tentang pengertian volume pada bangun ruang, sifat-sifat dan unsur-unsur balok. Selanjutnya siswa

melakukan penyelidikan yang juga melibatkan proses mengamati APM, mengumpulkan informasi, dan menalar dengan panduan LKS. Kegiatan ini dapat dilakukan secara berkelompok. Ada serangkaian pertanyaan dan perintah di LKS untuk mengarahkan siswa melakukan penyelidikan menggunakan APM dengan benar serta mengefisienkan waktu. Contoh pada materi volume balok, APM yang digunakan untuk penyelidikan berupa kubus satuan. Siswa diminta menyusun kubus satuan seperti pada gambar di LKS. Kemudian siswa mengisi di LKS terkait panjang, lebar, dan tinggi balok serta menentukan banyaknya kubus satuan yang membentuk balok tersebut. Berdasarkan hasil percobaan yang dilakukan, siswa menyimpulkan bahwa volume balok adalah hasil kali panjang, lebar, dan tingginya. Setelah melakukan penyelidikan, siswa perlu menuliskan hasil penyelidikan di LKS. Guru memberikan kesempatan kepada beberapa siswa untuk mempresentasikan hasil penyelidikan di depan kelas. Siswa lain diberi kesempatan untuk menanggapi hasil penyelidikan temannya. Guru mengarahkan agar proses diskusi kelas berjalan lancar dan kesimpulan hasil penyelidikan benar. Siswa secara berkelompok menyelesaikan permasalahan yang telah diamati sebelumnya menggunakan rumus yang telah diperoleh pada tahap penyelidikan. Setelah itu, salah satu siswa mempresentasikan hasil penyelesaian masalah. Guru membahas hasil pekerjaan siswa dan memberikan penguatan yang diperlukan. Setelah itu, siswa diberikan soal-soal latihan terkait materi yang diperlukan. Soal latihan tersebut berupa permasalahan di lingkungan sekitar yang sesuai dengan topik yang dipelajari. Soal diberikan untuk melatih siswa terampil dalam menyelesaikan masalah nyata menggunakan rumus luas atau volume bangun ruang. Soal-soal pemecahan masalah yang menekankan open ended, penalaran dan berpikir kritis akan melatih siswa menyelesaikan permasalahan.

Topik geometri ruang yang dipelajari di SMP meliputi luas dan volume kubus, balok, prisma, limas, tabung, kerucut, bola dan bangun ruang yang tidak beraturan. Berbagai APM dan benda yang ada di lingkungan sekitar siswa dapat dipilih untuk mendukung kegiatan penyelidikan manipulatif. Pada penelitian ini,
APM yang digunakan adalah alat peraga bangun ruang yang sudah ada di sekolah yaitu berupa model kubus, balok, prisma, limas, tabung, kerucut, dan bola. Alat peraga tersebut bisa digunakan untuk mengenalkan unsur-unsur bangun ruang. Beberapa alat peraga bangun ruang dirancang sehingga dapat digunakan dalam kegiatan penyelidikan manipulatif menentukan rumus luas dan volume bangun ruang. Selain APM, lingkungan dapat digunakan sebagai sumber belajar berbagai topik geometri ruang. Penggunaan lingkungan dalam penelitian ini berupa benda di lingkungan sekitar yang bisa difungsikan sebagai alat peraga untuk penyelidikan ataupun masalah sehari-hari di lingkungan sekitar terkait topik-topik bangun ruang. Sebagai contoh, pada topik kubus dapat diajarkan dengan menggunakan APM model kubus dengan berbagai ukuran untuk menjelaskan sifat-sifat dan unsur-unsur kubus. APM luas kubus atau APM jaring-jaring kubus dapat digunakan untuk kegiatan penyelidikan luas kubus. APM kubus satuan dapat digunakan untuk penyelidikan volume kubus. Selain menggunakan APM, benda atau permasalahan di lingkungan sekitar yang berbentuk kubus. Misalnya kardus snack, dadu, balon kubus, dan lain-lain.

Penelitian ini juga menghasilkan prototipe APM berupa APM bangun ruang lipat. APM dibuat dari bahan kertas BC berwarna yang dilaminating. APM ini, berupa jaring-jaring bangun ruang yang di beberapa rusuknya diberi pengunci dari mika serta dapat dilipat.

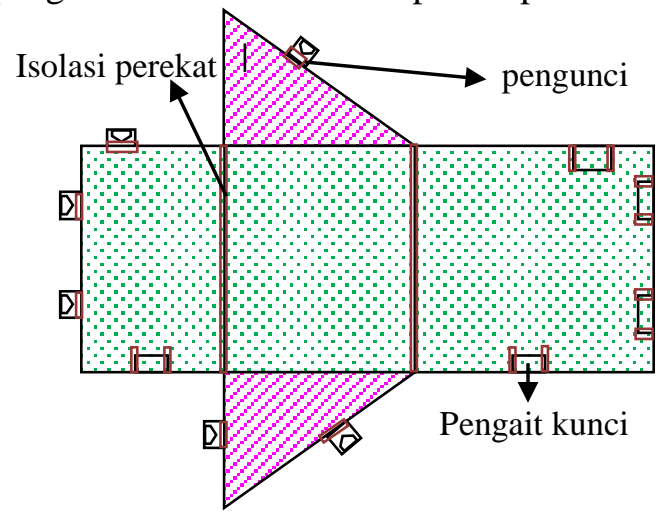

Gambar 2. Desain APM

Adanya pengunci memungkinkan alat peraga ini dapat digunakan untuk berbagai manfaat dalam satu alat peraga yaitu dapat digunakan untuk menentukan unsur-unsur bangun ruang, jaring-jaring, luas permukaan serta volume bangun ruang tersebut. 
Tabel 3. Penggunaan APM

Penggunaan
Bentuk dasar, ada beberapa pengunci
dari mika transparan pada jaring-jaring
bangun ruang
Untuk menjelaskan unsur-unsur bangun
ruang, kaitkan semua pengunci sehingga
membentuk model bangun ruang
Untuk menentukan jaring-jaring dan luas
permukaan bangun ruang, buka semua
pengunci sehingga membentuk jaring-
jaring
Untuk menentukan volume bangun ruang
bangun ruang, buka satu pengunci yaitu
bagian tutup balok, kubus, prisma dan
bagian alas limas
Untuk penyimpanan bangun ruang, lipat
dan masukkan menjadi satu ke plastik
ukuran folio

RPP, LKS, Lembar Observasi Sikap (LOS), dan Tes Hasil Belajar (THB) dibuat pada tahap design berdasarkan hasil analisis pada tahap define, kemudian dilakukan validasi ahli dan uji coba lapangan pada tahap develop. Proses revisi dan evaluasi selalu dilakukan sampai dihasilkan produk akhir yang valid, praktis, dan efektif. Berikut ini disajikan pembahasan tentang tingkat kevalidan, kepraktisan, dan keefektifan perangkat yang dihasilkan sampai pada tahap akhir uji keseluruhan.

\section{Kevalidan Produk}

Kevalidan produk ditentukan berdasarkan hasil penilaian ahli menggunakan lembar validasi perangkat. Penilaian ahli ini dilakukan untuk melihat validitas isi dari Draf I Perangkat. Hasil penilaian dari validator diperoleh semua aspek yang dinilai dalam kategori valid dan perangkat layak digunakan dengan sedikit revisi.

Tabel 4. Tingkat Kevalidan Produk

\begin{tabular}{|c|c|c|c|c|}
\hline Produk & RPP & LKS & LOS & THB \\
\hline $\begin{array}{l}\text { Banyak Item } \\
\text { Penilaian }\end{array}$ & 50 & 20 & 9 & 15 \\
\hline $\begin{array}{l}\text { Banyak Item yang } \\
\text { Valid Menurut } \\
\text { Validator I }\end{array}$ & 50 & 20 & 9 & 15 \\
\hline $\begin{array}{l}\text { Banyak Item yang } \\
\text { Valid Menurut } \\
\text { Validator II }\end{array}$ & 50 & 20 & 9 & 15 \\
\hline $\begin{array}{l}\text { Tingkat Kevalidan } \\
\text { Produk }\end{array}$ & $100 \%$ & $100 \%$ & $100 \%$ & $100 \%$ \\
\hline
\end{tabular}

Hasil penilaian ahli pada item-item yang menjadi indikator penilaian di lembar validasi menunjukkan bahwa perangkat telah memenuhi standar validasi isi, yaitu validitas logis (logical validity) dan validitas muka (face validity). Validitas logis meliputi terpenuhinya pengembangan perangkat yang diketahui dari kesesuaian antara perangkat yang dikembangkan dengan stándar isi maupun standar proses Kurikulum 2013, kesesuaian perangkat yang dikembangkan dengan aspek kognitif dan tingkat perkembangan mental siswa, serta kebenaran perangkat yang dikembangkan. Validitas muka meliputi terpenuhinya indikator kejelasan perangkat dari aspek bahasa dan kejelasan sajian perangkat.

Hasil validasi tersebut sesuai dengan Plomp \& Nieveen (2010, p.26) bahwa suatu produk dikatakan valid apabila, “... the components should be based on state-of-the art knowledge (content validity)". Berdasarkan penilaian ahli, perangkat yang dikembangkan telah memenuhi berbagai teori terkait teori pembelajaran matematika, materi geometri ruang SMP, pengembangan perangkat pembelajaran, dan pemilihan sumber belajar.

Seperti yang dijelaskan sebelumnya, lembar validasi perangkat berupa checklist pada kolom valid dan tidak valid pada setiap indikator penilaian dan apabila ada indikator yang belum valid maka dilakukan revisi dan konsultasi dengan ahli. Proses revisi terus dilakukan sampai dihasilkan perangkat yang valid dan siap untuk digunakan pada tahap uji pengembangan. Dengan demikian, tingkat kevalidan perangkat (RPP, LKS, LOS dan THB) yang dihasilkan masing-masing mencapai $100 \%$.

\section{Kepraktisan Produk}

Kepraktisan produk dianalisis berdasarkan hasil observasi keterlaksanaan pembelajaran, penilaian kepraktisan LKS dan THB oleh siswa, penilaian kepraktisan RPP, LKS, LOS dan THB oleh guru.

Hasil penilaian siswa menunjukkan LKS dan THB mudah dibaca dan digunakan. Hasil penilaian guru menunjukkan perangkat (RPP, LKS, LOS, dan THB) mudah dibaca dan digunakan. Tingkat kepraktisan setiap produk berdasarkan penilaian guru dan siswa ditunjukkan pada Tabel 5.

Tabel 5. Tingkat Kepraktisan Produk

\begin{tabular}{ccccc}
\hline Produk & RPP & LKS & LOS & THB \\
\hline Penilaian Guru & $100 \%$ & $100 \%$ & $100 \%$ & $84,61 \%$ \\
Penilaian Siswa & - & $100 \%$ & - & $84,12 \%$ \\
Tingkat & $100 \%$ & $100 \%$ & $100 \%$ & $84,36 \%$ \\
Kepraktisan & & & & \\
Produk & & & & \\
\hline
\end{tabular}




\section{Pythagoras, 10 (2), Desember 2015 - 164}

Harna Yulistiyarini, Ali Mahmudi

Hasil observasi keterlaksanaan pembelajaran menunjukkan lebih dari $75 \%$ aktivitas pembelajaran terlaksana. Tingkat keterlaksanaan pembelajaran pada uji keseluruhan adalah $97 \%$.

Tabel 6. Keterlaksanaan Pembelajaran pada Uji Keseluruhan di Kelas VIII-E

\begin{tabular}{|c|c|c|c|c|}
\hline \multirow[t]{2}{*}{$\begin{array}{c}\text { Pertemuan Ke- / } \\
\text { Materi }\end{array}$} & \multicolumn{3}{|c|}{$\begin{array}{c}\text { Jumlah } \\
\text { Keterlaksanaan } \\
\text { Aktivitas }\end{array}$} & \multirow[t]{2}{*}{ Persen } \\
\hline & Siswa & Guru & Total & \\
\hline 1/ Luas Kubus & 19 & 28 & 47 & $90 \%$ \\
\hline 2/ Luas Balok & 22 & 30 & 52 & $100 \%$ \\
\hline 3/ Luas Prisma & 22 & 29 & 51 & $98 \%$ \\
\hline 4/ Luas Limas & 22 & 30 & 52 & $100 \%$ \\
\hline 5/ Volume Kubus & 21 & 29 & 50 & $96 \%$ \\
\hline 6/ Volume Balok & 21 & 29 & 50 & $96 \%$ \\
\hline 7/ Volume & 21 & 29 & 50 & $96 \%$ \\
\hline \multicolumn{5}{|l|}{ Prisma } \\
\hline 8/ Volume Limas & 21 & 28 & 49 & $94 \%$ \\
\hline \multicolumn{5}{|l|}{ tidak beraturan } \\
\hline Rata-rata Keterla & anaan & embel & $\operatorname{aran}$ & $97 \%$ \\
\hline
\end{tabular}

Secara umum perangkat yang dikembangkan praktis digunakan karena dapat digunakan/ diterapkan, mudah digunakan, dan dapat membantu siswa dalam belajar. Hal ini sesuai dengan Plomp \& Nieveen (2010, p.26), "practicality if end-users (for instance the teachers and learner) consider the intervention to be usable and that it is easy for them to use the materials in a way that is largely compatible with the developers' intentions". Jadi, perangkat yang dikembangkan sampai tahap terakhir uji pengembangan telah memenuhi aspek kepraktisan.

Kelemahan pemanfaatan APM dan lingkungan yang dikemukakan pada hasil survei Marshall \& Paul (2008) dapat diminimalisir. Kurang tersedianya APM di sekolah dan masalah biaya pengadaan APM dapat diminimalisir dengan penggunaan benda di lingkungan sekitar siswa sebagai pengganti APM dan pembuatan APM dari bahan yang terjangkau. Masalah kebisingan siswa tidak terjadi karena sejak awal siswa telah diberitahu tentang adanya penilaian sikap selama pembelajaran. Masalah penyalahgunaan APM diatasi dengan adanya LKS yang menuntun siswa untuk melakukan penyelidikan dengan benar serta adanya tuntutan bahwa setiap kelompok harus mempresentasikan hasil penyelidikan di depan kelas. Terkait penyimpanan APM yang selama ini menjadi masalah bagi guru dapat diatasi dengan pembuatan prototipe APM yang dapat dilipat serta multifungsi. Adanya petunjuk penggunaan APM membantu guru untuk memahami cara pemanfaatan APM. Hal ini meningkatkan keyakinan diri guru sehingga guru merasa mampu menggunakan APM dengan benar. Adanya LKS yang dimiliki setiap siswa dan APM yang lengkap serta dalam jumlah yang cukup memungkinkan efisiensi waktu untuk pelaksanaan pembelajaran.

\section{Keefektifan Produk}

Keefektifan produk yang dikembangkan dilihat dari ketuntasan perolehan hasil belajar. Hal ini berdasarkan penjelasan Plomp \& Nieveen (2010, p.26), bahwa hasil penelitian pengembangan dikatakan efektif jika menghasilkan sesuatu sesuai dengan tujuan yang diharapkan (the intervention results in desired outcome). Rochmad (2012, p.71) pun memaparkan bahwa indikator keefektifan bergantung pada pendefinisian yang dimaksud efektif dalam penelitian tersebut, misalnya hasil belajar siswa, aktivitas siswa, kemampuan siswa dalam matematika, dan tingkat penghargaan siswa terhadap produk dan keinginan siswa untuk terus menggunakan produk tersebut. Pada penelitian ini, penelitian dikatakan efektif apabila nilai ketuntasan klasikal melebihi 75\%. Pada Kurikulum 2013, siswa dinyatakan tuntas jika nilai sikap minimal $\mathrm{B}$, rerata pengetahuan minimal 2,67 dan nilai keterampilan minimal 2,67.

Hasil penilaian pada uji keseluruhan menunjukkan nilai sikap siswa pada tahap uji keseluruhan menunjukkan $81 \%$ siswa berkategori sangat baik dan 19\% siswa kategori baik. Jadi, pada aspek sikap semua siswa tuntas. Hasil penilaian ketercapaian pengetahuan siswa diperoleh $85,71 \%$ siswa tuntas dengan rata-rata kelas 3,2 pada skala 4 . Hasil penilaian keterampilan siswa diperoleh $85,71 \%$ dengan rata-rata kelas 3,05 pada skala 4 .

Tabel 7. Ringkasan Hasil Belajar Siswa pada Uji Keseluruhan di Kelas VIII-E

\begin{tabular}{cccc}
\hline Keterangan & Sikap & Pngetahuan & Kterampiln \\
\hline Nilai tertinggi & $\mathrm{A}$ & 4 & 4 \\
Nilai terendah & $\mathrm{B}$ & 2 & 2,08 \\
Nilai rata-rata & - & 3,2 & 3,055 \\
KKM & $\mathrm{B}$ & 2,67 & 2,67 \\
Banyak & 21 & 18 siswa & 18 siswa \\
siswa tuntas & siswa & & \\
Persentase banyak & $100 \%$ & $85,71 \%$ & $85,71 \%$ \\
siswa yang tuntas & & & \\
\hline
\end{tabular}

Jika ditinjau dari ketuntasan pada ketiga aspek sekaligus, siswa yang tuntas pada ketiga aspek sebanyak 17 siswa atau sekitar $81 \%$. Hal ini menunjukkan perangkat yang dihasilkan 


\section{Pythagoras, 10 (2), Desember 2015 - 165}

Harna Yulistiyarini, Ali Mahmudi

(RPP dan LKS) telah memenuhi tujuan yang diharapkan yaitu nilai ketuntasan klasikal pada ketiga aspek lebih dari $75 \%$.

Keefektifan perangkat pembelajaran dengan memanfaatkan APM dan lingkungan sekitar sebagai sumber belajar ini sesuai dengan beberapa penelitian terdahulu. Hasil ini sesuai dengan PTK Goracke (2009) yaitu penggunaan APM pada pembelajaran matematika kelas delapan dapat meningkatkan sikap dan pemahaman siswa.

\section{SIMPULAN DAN SARAN}

\section{Simpulan}

Pengembangan perangkat pembelajaran geometri ruang SMP berbasis Kurikulum 2013 dengan memanfaatkan alat peraga manipulatif dan lingkungan dilaksanakan dengan mengadaptasi prosedur pengembangan perangkat dengan model Four-D yang dimodifikasi menjadi tiga tahapan yaitu: (1) tahap define, (2) tahap design, dan (3) tahap develop. Dalam prosedur tersebut juga mencakup beberapa kali revisi sesuai masukan saat penilaian ahli maupun uji pengembangan yang meliputi tiga tahap uji coba lapangan yaitu uji awal, uji kuantitatif, dan uji keseluruhan. Perangkat yang dikembangkan berupa RPP, LKS, LOS, dan THB dibuat dengan mengacu pada peraturan Kurikulum 2013. RPP dan LKS yang dihasilkan memuat kombinasi pemanfaatan alat peraga manipulatif dan lingkungan.

Tingkat kevalidan RPP, LKS, LOS, dan THB mencapai $100 \%$. Tingkat kepraktisan RPP, LKS, dan LOS mencapai $100 \%$ sedangkan tingkat kepraktisan THB yaitu $84,36 \%$. Tingkat keterlaksanaan pembelajaran yaitu $97 \%$. Tingkat keefektifan produk RPP dan LKS mencapai $81 \%$. Jadi, dapat disimpulkan produk hasil pengembangan yang berupa RPP dan LKS memenuhi kriteria valid, praktis, dan efektif, serta instrumen penilaian yang berupa THB dan LOS memenuhi kriteria valid dan praktis.

\section{Saran Pemanfaatan Produk}

Produk perangkat geometri ruang yang dikembangkan dapat digunakan sebagai referensi dan bahan masukan para guru dalam menyusun bahan ajar geometri ruang SMP dengan memanfaatkan alat peraga manipulatif dan lingkungan pada pembelajaran di kelas.

Selain itu, pengembangan perangkat berbasis Kurikulum 2013 dengan memanfaatkan alat peraga manipulatif dan lingkungan ini hanya terbatas pada materi geometri ruang sehingga disarankan agar peneliti lain dapat mengembangkan pada materi lainnya.

\section{DAFTAR PUSTAKA}

Adams, D., \& Hamm, M. (1994). New design for teaching and learning. San Fransisco, CA: Jossey Boss Publisher.

Al-Absi, M. M., \& Nofal, M. B. (2013). The effect of using manipulatives on the mathematical achievement of the first grade students. Damascus University Journal, 26(4), 37-54. Diakses tanggal 5 Juni 2015 dari www.damascus university.edu.sy/mag.

Arsyad, A. (2011). Media pembelajaran. Jakarta: PT Raja Grafindo Persada.

Baur, G. R., \& Pigford, D. (1984). A survival guide for the junior high/middle school mathematics teacher. West Nyack, NY: Parker Publishing Company, Inc.

Boggan, M., Harper, S., \& Whitmire, A. (2010). Using manipulatives to teach elementary mathematics. Journal of Instructional Pedagogies, 3(1), 1-10. Diakses tanggal 5 Juni 2015 dari http://www.aabri.com/ manuscripts/10451.pdf.

Burns, M. (2007). About teaching mathematics: A $K-8$ resource ( $3^{\text {th }}$ ed.). Sausalito, CA: Math Solution Publications.

Cope, L. (2015). Math manipulatives: Making the abstract tangible. Delta Journal of Education. 5(1), 10-19. Diakses tanggal 5 Juni 2015 dari http://www.deltastate.edu/ PDFFiles/DJE/spring2015/dje_spring_20 15 cope- final.pdf.

Drews, D. \& Hansen, A. (Eds.). (2007). Using resources to support mathematical thinking primary and early years. Southernhay East: Learning Matters Ltd.

Frei, S. (2008). Teaching mathematics today. Huntington Beach, CA: Shell Education.

Goos, M., Stillman, G. \& Vale, Collen. (2007). Teaching secondary school mathematics research and practice for the 21 century. Crows Nest, NSW: Allen \& Unwin

Goracke, M. A. (2009). The role of manipulatives in the eighth grade mathematics classroom. Action Research Projects. Paper 71. Diakses tanggal 13 


\section{Pythagoras, 10 (2), Desember 2015 - 166}

Harna Yulistiyarini, Ali Mahmudi

September 2014 dari http://digitalcom mons.unl.edu/mathmidactionresearch/71

Groth, R. E. (2013). Teaching mathematics in grades 6-12 developing research-based instructional practises. Thousand Oaks, CA: Sage Publicatins, Inc.

Hamalik, O. (2005). Proses belajar mengajar. Jakarta: PT. Bumi Aksara.

Januszewski, A., \& Molenda, M. (Eds). (2008). Educational technology: A definition with commentary. New York, NY: Taylor \& Fancis Group.

Kamina, P., \& Iyer, N. N. (2009). From concrete to abstract: Teaching for transfer of learning when using manipulatives. Nera Conference Prosiding. Diakses pada tanggal 5 Juni 2015 dari http://digitalcommons. uconn.edu/nera 2009/6/

Kelly, C. A. (2006). Using manipulatives in mathematical problem solving: A performance-based analysis. The Montana Mathematics Enthusiast, 3(2), 184-193. Diakses tanggal 5 Juni 2015 dari http://citeseerx.ist.psu.edu/viewdoc/ download?doi $=10.1 .1 .134 .4216 \&$ rep $=$ rep $1 \&$ type $=$ pdf $\#$ page $=61$

Kennedy, L. M., Tipps, S., \& Johnson, A. E. (2008). Guiding children's learning of mathematics $\left(11^{\text {th }}\right.$ ed.). Belmont, CA: Thomson Higher Education.

Kemdikbud. (2014). Peraturan Menteri Pendidikan dan Kebudayaan Nomor 58, Tahun 2014, tentang Kurikulum 2013 Sekolah Menengah Pertama/Madrasah Tsanawiyah.

Kosko, K. W. \& Wilkins, J. L. M. (Juli 2010). Mathematical communication and its relation to the frequency of manipulative use. International Electronic Journal of Mathematics Education 5(2). Diakses tanggal 13 September 2014 dari www.iejme.com

Majid, A. (2013). Perencanaan pembelajaran. Bandung: PT Remaja Rosdakarya.

Marshall, L., \& Paul, S. (2008). Exploring the use of mathematics manipulative materials: is it what we think it is? Originally published in the Proceedings of the EDU-COM 2008 International
Conference. Sustainability in Higher Education: Directions for Change, 19-21 November 2008. Page 338-350. Diakses tanggal 5 Juni 2015 dari http://ro.ecu.edu. $\mathrm{au} /$ ceducom/33/

Mink, D. V. (2010). Strategies for teaching mathematics. Huntington Beach, CA: Shell Education.

Muijs, D. \& Reynold, D. (2008). Effective teaching evidence and practice second edition. (Terjemahan Helly Prajitno Soetjipto \& Sri Mulyantini Soetjipto).Yogyakarta: Pustaka Pelajar. (Buku asli diterbitkan tahun 2008).

Mulyasa, H. E. (2014). Pengembangan dan implementasi Kurikulum 2013. Bandung: PT Remaja Rosdakarya.

Ojose, B., \& Sexton, L. (2009). The effect of manipulative materials on mathematics achievement of first grade students. The Mathematics Educator,12(1), 3-14. Diakses tanggal 5 Juni 2015 dari http://math.nie.edu.sg/ame/matheduc/tme/ tmeV12_1/04\%20TME(12-)\%20The\%20 Effects\%20of\%Math\%Manipulatives.pdf

Plomp, T., \& Nieveen, N (Eds.). (2010). An introductional to educational design research. 3rd print. In Proceedings of the seminar conducted at the East China Normal University, Shanghai (PR China), November 23-26, 2007. Enschede, Netherland: SLO-Netherlands institute for curriculum development.

Posamentier, A. S, Smith, B. S., \& Stepelman, J. (2010). Teaching secondary mathematics: teaching and enrichment units. ( $8^{\text {th }} e d$.). Boston, MA: Allyn \& Bacon.

Rochmad. (2012). Desain model pengembangan perangkat pembelajaran. Jurnal Kreano, 3(1), 59-72.

Sadiman, A. S., Rahardjo, R., Haryono, A., et al. (2011). Media pendidikan: pengertian, pengembangan dan pemanfaatannya. Jakarta: Rajawali Press

Smaldino, S. E., Lowther, L. D., \& Russel, J. D. (2008). Instructional technology and media for learning. Upper Saddle River, NJ: Pearson Prentice Hall.

Thiagarajan, S., Semmel, D., \& Semmel, D. (1974). Instructional development for 
Pythagoras, 10 (2), Desember 2015 - 167

Harna Yulistiyarini, Ali Mahmudi

training teachers of exceptional children,

a source book. Bloomington, Indiana: Indiana University.
Trianto. (2009). Mendesain model pembelajaran inovatif-progesif. Jakarta: Kencana Prenada Media Grup. 